\author{
IRENA SAWICKA \\ Instytut Slawistyki Polskiej Akademii Nauk \\ ORCID: 0000-0003-1426-8211
}

\title{
Rozważania o tureckich sufiksach w języku macedońskim
}

\begin{abstract}
A b s t r a k t: Artykuł wylicza problemy gramatyczne/morfonologiczne, jakie generują na gruncie języka macedońskiego sufiksy zapożyczone z języka tureckiego. Główny temat stanowią rozważania o etymologii słowiańskiego sufiksu deminutywno-hipokorystycznego -če. Pod uwagę brany jest ewentualny wpływ turecki na utrwalenie i frekwencję tego sufiksu.
\end{abstract}

S łow a k lu c z e : język macedoński; zapożyczenia tureckie; słowotwórstwo; sufiksy; etymologia

Temat artykułu dotyczy przyrostków pochodzenia tureckiego. Posługiwać się będę przykładami z języka macedońskiego, ale w zasadzie temat dotyczy w znacznym stopniu także bułgarskiego i języków BCMS. W słoweńskim, kajkawskim i czakawskim turcyzmów jest znacznie mniej i są uważane za pożyczki z sąsiednich języków słowiańskich (Pintarič 2012).

Wpływ języka i kultury tureckiej na wszelką aktywność intelektualną bałkańskich Słowian jest zdecydowanie zaniedbany. W szczególności dotyczy to języka (liczne prace dotyczą głównie zapożyczeń leksykalnych). Za ten niedostatek odpowiedzialny jest brak wzajemnych kompetencji po obu 
stronach - slawistów i turkologów ${ }^{1}$, ale także szczególna filozofia uprawiana na słowiańskich Bałkanach w postaci, między innymi, inżynierii językowej, mająca na celu wyrugowanie z języka wszelkich śladów po byłym, znienawidzonym okupancie. Przejawia się to głównie w usuwaniu turcyzmów. W ten sposób znika powoli temat badawczy. Turcyzmy funkcjonują jeszcze, coraz słabiej, w języku potocznym. Językoznawcy macedońscy nie angażują się w te działania w takim stopniu jak serbscy czy bułgarscy językoznawcy dlatego też materiał macedoński pochodzenia tureckiego jest łatwiej dostępny i z tego względu został tu wybrany do egzemplifikacji zagadnienia.

Przyrostki pochodzenia tureckiego sprawiają strukturze językowej słowiańskiej najróżniejsze problemy. Mimo iż dobrze funkcjonują w języku, nie zawsze podporządkowują się słowiańskiej strukturze językowej. Tureckie pożyczki przechodzą na Bałkanach przez indoeuropejskie sito i czasami powstają nieoczekiwane i chaotyczne rezultaty.

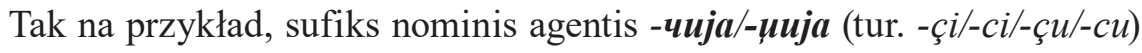
występuje w macedońskim w dwóch postaciach morfonologicznych, których dystrybucja nie da się objaśnić na gruncie języka słowiańskiego. Ten sufiks wszedł do macedońskiego za pośrednictwem zapożyczeń tureckich i z czasem stał się, podobnie jak inne sufiksy pochodzenia tureckiego, niezwykle produktywny także przy podstawach słowiańskich. Według Petii Asenovej zawdzięcza to swojej jednoznaczności i przejrzystości słowotwórczej (por. о tym Асенова 2002: 65, także Długosz 2020). Jest jednak kompletnie nieinterpretowalny morfonologicznie. Zderzają się tu reguły słowiańskiego sandhi z turecką harmonią konsonantyczną. Słowiańskie reguły mają kierunek regresywny, tureckie - progresywny. To wcale nie znaczy, że turecka harmonia konsonantyczna działa w materiale słowiańskim. Kształt fonetyczny tematu słowotwórczego zależy od przyłączanego wariantu przyrostka wygłosowy obstruent tematu słowotwórczego przystosowuje się pod względem dźwięczności do nagłosowej spółgłoski sufiksu. Natomiast sam wybór tego wariantu jest chaotyczny, por. np. mac.:

- po obstruencie bezdźwięcznym: чифчија 'dzierżawca', бурекчија 'producent burka', кебапчија 'producent kebabu';

${ }_{1}$ Mnie również brakuje niezbędnych kompetencji. We wszystkich kwestiach dotyczących języka tureckiego opieram się na wiedzy profesora Marka Stachowskiego - za jej udostępnianie jestem mu nieustannie wdzięczna. Marek Stachowski jest też autorem wszystkich komentarzy w tym artykule dotyczących języka tureckiego. 
- po obstruencie dźwięcznym: чифлигиија 'dzierżawca' ловиија 'myśliwy'.

Zgodność spółgłosek pod względem dźwięczności na styku morfemów wynika z działania regresywnego upodobnienia, ale nie ma wpływu na wybór formy morfonologicznej sufiksu. W powyższych przykładach pozornie wszystko zgodne jest z harmonią konsonantyczną, ale mamy też зграпчиja 'łapacz' od macedońskiego граби 'łapie', ќерамидиија 'producent dachówek' od tureckiego kiremit 'dachówka'. Przyznać jednak trzeba, że takich „odstępstw” od tureckiej reguły jest w macedońskim mniej niż w serbskim, co zrozumiałe, jeśli wziąć pod uwagę różnie intensywną obecność Turków na Bałkanach w poszczególnych miejscach.

Po rezonantach mamy różne formy fonetyczne sufiksu, por.:

- po samogłosce: алвација 'stolarz', папуција 'szewc', силеицја 'gwałciciel', кочија 'wоźnica', гледичија 'stróż';

- po sonancie: фенериија 'zapalacz miejskich lamp', големиија 'wielkolud', ќррчиja 'hodowca indyków'.

Tak samo wygląda dystrybucja -чuja/-uuja w języku serbskim, nieco lepiej, ale też nie do końca dystrybucja jest uporządkowana w bułgarskim (a także w albańskim, gorańskim, rumuńskim i greckim). Między językami i nawet w ramach jednego języka, obserwujemy różne decyzje, por. serbskie dublety: caxamчuja [saxattfija], też caxaчuja [saxatfija] i caxaųuja [saxadzija] 'zegarmistrz'; serb. тобција 'artylerzysta' od mon 'armata', ale bułg. monчuja, (tur. topçu). Więcej na ten temat zob. w: Sawicka, Karasiński 2018.

Inny sufiks pochodzenia tureckiego -лијa (tur. -li/-lu) był także bardzo produktywny w macedońskim i także derywuje od podstaw nietureckich, np. mac. зејтинлија 'coś w kolorze oliwy', портокалија 'sprzedawca pomarańcz', среќлија 'szczęściarz', атлија 'posiadacz konia, jeździec' itp. Ten sufiks na gruncie słowiańskim stał się ambiwalentny gramatycznie (por. Sazdov 2019, Тополињска 1979). Są to w większości nomina atributiva ${ }^{2}$, ale składniowo formacje z tym sufiksem zachowują się heterogenicznie na tyle, że nie wiadomo do jakiej kategorii fleksyjnej należy je zaliczyć - do rzeczowników czy przymiotników. W słownikach języka macedońskiego sufiks ten jest traktowany niekonsekwentnie - niektóre przykłady z tym sufiksem

2 Zasadniczo oba sufiksy, -чија/-ција і -лија, obsługują te same znaczenia, ale o ile przy -чuја/-ција przeważają formacje o znaczeniu nomina agentis, to przy -лија znaczenia atrybutywne. 
mają kwalifikator 'rzeczownik', inne 'przymiotnik'. Podobnie językoznawcy. Nasteva (Јашар-Настева 2001) uważa, że formacje z sufiksem -лијa to zapożyczenia leksykalne, ale wymienia je również, kiedy mówi o zapożyczeniach sufiksów i także określa je bądź jako przymiotniki, bądź rzeczowniki. Korubin skłania się do traktowania formacji z -лиja jako rzeczowniki (Корубин 1990). Według Skoka (1971: 295) są to formacje rzeczownikowe i w języku serbskim obsługują te same znaczenia co przyrostki rodzime-telj, -ac i -janin.

Jako przymiotniki formacje $\mathrm{z}$-лиja nie są stopniowalne, nie mają też rodzaju gramatycznego. Są więc pod względem fleksyjnym bardziej podobne do rzeczowników3. W macedońskim języku tworzą także formy żeńskie przy pomосу sufiksu -ка, np. мераклија 'człowiek, który bardzo czegoś pragnie' - мераклика, среќлија 'szczęściarz' - среќлика, ксметлија 'szczęściarz' ксметлика.

Według Topolińskiej kwalifikacja derywatów z -лиja do odpowiedniej klasy morfologicznej bywa różna; w zależności od konkretnego leksemu mogą być przymiotnikami lub rzeczownikami, ale większość z nich to, jej zdaniem, hybrydy przymiotnikowo-rzeczownikowe (Тополињска 1979).

W starszych tekstach, zwłaszcza ludowych, sufiks ten używany jest często bez poszerzenia -ja - ta forma funkcjonuje zawsze jako przymiotnikowa. W języku serbskim, gdzie istnieje fleksja przypadkowa, formy bez -ja są nieodmienne, np. pamukli-košulja 'koszula bawełniana' - gen.sg. pamukli-košulje, acc.sg. pamukli-košulju. Derywaty z formą poszerzoną -lija są traktowane w serbskich słownikach konsekwentnie jako rzeczowniki (zob. np. w Речник српскохрватскога књижевног језика 1967-1976), a te $\mathrm{z}$-li jako przymiotniki.

Jeśli idzie o macedoński, zasadniczo nie ma wątpliwości co do formy na $-л и$, która tworzy derywaty przymiotnikowe, natomiast derywaty z -лија $\mathrm{w}$ tekstach naukowych są traktowane heterogenicznie z przewagą interpretacji rzeczownikowej. Inaczej w starszych słownikach, gdzie przeważa interpretacja przymiotnikowa.

3 Wprawdzie istnieją w macedońskim inne przymiotniki bez wyrażonego gramatycznie rodzaju, jak np. фер 'lojalny, uczciwy' сzy секси 'seksowny' - te jednak dają się stopniować: секси - посекси, најсекси, itp. Z drugiej strony niektóre rzeczowniki nazywające cechy także mogą się stopniować, np. junak 'bohater' - pojunak, najjunak. 
Inny sufiks turecki -lık (-lik, -luk, -lük) tworzący nomina abstracta w językach słowiańskich najczęściej upowszechnił się w jednej formie, wybranej spośród alomorfów tureckich (jak w serbskim, gdzie mamy -luk), lub też w formie zawierającej refleks wtórnego wokalizmu (jak w bułgarskim, gdzie mamy -лък). Sądzić więc można, że w tym wypadku zapożyczona była forma turecka -lık. W rumuńskim mamy -lic, a w greckim - $\lambda \imath \kappa \eta$, które zapewne pochodzą z tureckiego -lik. W albańskim i macedońskim występują różne formy. W albańskim mamy formy -llëk, -llik, -lluk, których dystrybucja nie da się wytłumaczyć na gruncie języka albańskiego - jeśli jest zapożyczony cały leksem turecki to forma sufiksu zależy od harmonii wokalicznej, ale oczywiście nie tłumaczy się na gruncie albańskim, podobnie jak formacje z tym sufiksem przy podstawie nietureckiej, gdzie wybór alomorfu jest przypadkowy. Podobnie jest w gorańskim (zob. Długosz 2020). W macedońskim występują dwie formy, częstsza jest -лак, por. np. будалак і будалштилаk 'głupie zachowanie', простотилак 'prymitywizm', поганштилак 'pogaństwo', ale też -лук: безобразлук 'bezczelność', домакиилук 'domatorstwo'. Ta druga forma musiała przejść przez pośrednictwo serbskie. Samogłoska $\mathrm{w}$ formie -лак jest identyczna z refleksem wtórnego wokalizmu, więc zapewne pochodzi z tureckiego $-l i k$.

Wyrażenia z tymi sufiksami w większości funkcjonują na poziomie dialektalnym lub w języku (bardzo) potocznym.

Tutaj chciałabym się przyjrzeć pochodzeniu sufiksu -чe, który jest jednym z najbardziej produktywnych sufiksów deminutywno-hipokorystycznych w językach południowosłowiańskich. W słowniku a tergo języka macedońskiego ${ }^{4}$ naliczyłam blisko 1000 wyrazów z tym zakończeniem, z których większość, to formacje deminutywne z tym sufiksem. Podobnie w gorańskim $^{5}$, por. , ,[...] przyrostki -çe oraz -içe są najbardziej produktywnymi formantami deminutywnymi w języku naszenskim, a ich pole derywacyjne jest bardzo rozległe" (Reczek 2009: 6).

We wszystkich opracowaniach słowotwórczych, w których jest mowa o pochodzeniu tego sufiksu, traktowany jest on jako słowiański (np. Klajn 2003: 352 wymienia go wśród sufiksów słowiańskich). Moim zdaniem przekonanie o pochodzeniu słowiańskim wynika głównie stąd, że postać -чe/-če

${ }^{4}$ http://www.pelister.org/linguistics/revdict/085.html (dostęp 1.04.2021).

5 Gorański traktuję jako dialekt języka macedońskiego. 
brzmieniem przypomina inne słowiańskie sufiksy, por. np. serbskie unuče 'dziewczynka', vuče 'wilczek', gdzie č jest tematyczne i pochodzi z $k$ przed sufiksem -e pochodzącym $z$ *ee.

Istnieje wiele opracowań słowotwórczych języków południowosłowiańskich, w tym formacji deminutywnych (jak np. Аврамова 2016). Liczne są także opracowania deminutywów języka macedońskiego, zob. np. Дрвошанов 2012, Конески К. 1995, Аризанковска 2015, Јованова-Грујовска 2009, Sokołowski 2007, Соколовски 2013, 2018, Пановска 1973 i in., ale autorzy nie zastanawiają się nad pochodzeniem sufiksu i procesem derywacji. Nawet na niezwykle bogatej konferencji o słowiańskich deminutywach Manjšalnice v slovanskih jazikih (Stramljič Breznik 2015) nikt nie podjął tego tematu. Jedynym macedońskim badaczem, który wypowiedział się na ten temat, był Borys Markov (zob. dalej).

Wątpliwości co do słowiańskiego pochodzenia tego sufiksu nigdy dotąd zgłaszane nie były. W licznych opracowaniach formantów pochodzenia tureckiego sufiks -чe/-če nigdy nie był wymieniony (zob. np. Miklosich 1889, Belić 1901, 1904, Skok 1937/1938, Radić 2001, Јашар-Настева 2001, Petrović 1993, 2012, Корубин 1990, Škaljić 1966, Цветковски 2017, Stachowski S. 1971, 1973, 1967, Соболев 2004). Moim zdaniem warto jednak i w tym wypadku rozważyć hipotezę o pochodzeniu tureckim.

Mimo przekonania o słowiańskości -че nie istnieje żadna przekonująca propozycja etymologii tego sufiksu. W słownikach etymologicznych po postu nie jest wymieniany. Większość pracy nad tym artykułem polegała na bezskutecznym poszukiwaniu jakiejkolwiek etymologii tego sufiksu w pracach dotyczących słowiańszczyzny. Nie znalazłam jej nawet u Matasovicia, który omawia pochodzenie wszystkich słowiańskich nominalnych sufiksów (Matasović 2014). Znalazłam jedynie u Petra Skoka sugestię, że w tureckim może on być perskiego pochodzenia, por. „U turcizmima naročito perzijskog podrijetla, kao parče [...] i sam sufiks može biti perzijskog podrijetla" (Skok 1971: 170).

Jeszcze jeden etymolog wspomina o morfemie o takim samym brzmieniu. Ale ewidentnie chodzi tu o inną jednostkę - partykułę przysłówkową, występującą na wschodzie słowiańszczyzny. Por. „-че 1 - част. в составе слов нынче, ныньче, ноньче, болг. че 〈что〉 (Младенов 680), нж.-луж. vence 〈снаружи〉. Связано чередованием гласных с -ча (см.) из *ke $\|$ Возм., родственно др.-инд. $c a 〈$ 〈и, авест. $\check{c} a$, лат. quе, греч. $\tau \varepsilon$, но может 
также представлять ступень чередования вокализма относительно -ко, -ка, в последнем случае сюда же гомер., лесб., фессалийск. $x \varepsilon$ наряду с гомер. xєv (Бернекер I, 138; Сольсмен, KZ 35, 470 и сл.; GGA, 1889, 903)" (Фасмер 1987: 322). Oddzielnie omówiony jest wariant $\check{c} a$ z podobnymi przykładami: нынеча, тепереча (Фасмер 1987: 308).

Być może chodzi tu o ten sam morfem, może o inny, w każdym wypadku pochodzenia indoeuropejskiego, który mógł dotrzeć na południe słowiańszczyzny za pośrednictwem języka tureckiego (tam z perskiego?). Na południu słowiańskim także występuje forma $-\check{c} a$ (por. np. z tureckiego (?) mac. погаче, a w serbskim pogača 'ciasto') ${ }^{6}$ i jest to prawdopodobny wariant tego samego sufiksu, zarówno w świetle rozważań Fasmera, jak i w świetle tureckiej harmonii wokalicznej. W tureckim takie formy sufiksu również występują, zob. dalej.

Bardziej precyzyjnych opinii na temat etymologii -чe nie znalazłam.

Sufiks -чe/ -če bardzo dobrze funkcjonuje w językach południowo-słowiańskich, jest w pełni zintegrowany ze słowiańskim systemem fleksyjnym - w serbskim derywaty $\mathrm{z}$ tym sufiksem odmieniają się jak wyrazy rodzaju nijakiego na *-ęt-, np. parče 'kawałek' - gen. parčeta, јак ипис̌e 'wnuczek' - gen. unučeta. Tworzy też formy pluralne na wzór neutrów na -eleta, np. parčad jak unučad 'wnuczęta', telad 'cielęta', itd. Macedoński nie ma fleksji nominalnej przypadkowej, ale formy pluralne tworzą się na wzór formacji rodzimych, por. парче - парчиња, jak внуче - внучиња.

-че nie sprawia więc kłopotów gramatycznych, jak wyżej wymienione dwa tureckie sufiksy. Łatwo też kontaminuje się z innymi słowiańskimi sufiksami.

Ze względu na dobre funkcjonowanie w ramach słowiańskiego systemu słowotwórczego formacje z -чe są stabilne, w pełni zintegrowane z gramatyką słowiańską i z pewnością nie spotka ich taki los jak derywaty z -lija, -čija czy -luk, które, mimo jeszcze niedawnej wysokiej produktywności, powoli wychodzą z użycia, funkcjonując jeszcze na poziomie kolokwialnym7. De-

${ }^{6}$ Inna możliwa etymologia to włoskie focaccia/fogaccia? Albo znów identyfikacja leksemów różnego pochodzenia o podobnym brzmieniu i znaczeniu, a więc: w chorwackim z włoskiego i dalej do serbskiego, w macedońskim z tureckiego.

7 Moja macedońska informatorka, której jestem wdzięczna za pomoc - profesor Veselinka Labroska - często miała trudności z podaniem znaczenia wyekscerpowanych przeze mnie wyrazów z tymi sufiksami. 
rywaty z -чe mają wysoką frekwencję, używane są w każdej odmianie języka, sam przyrostek jest niezwykle produktywny, derywuje od rzeczowników różnych rodzajów, a także od podstaw werbalnych, por. mac. rodzime: nерчe 'piórko', зракче 'promyczek', оревче orzeszek', димче 'dymek', здравче 'zdrówko'; od podstaw tureckich: цамче 'meczecik', бадемче 'migdałek', фиданче 'drzewko', мепче 'kieszonka'; od nowszych pożyczek z innych języków: објектче 'obiekcik', кредитче 'kredycik', дипломатче 'dyplomata'; od podstaw czasownikowych: недоносче 'niedonosek'.

$\mathrm{Za}$ ewentualnym pochodzeniem tureckim przemawia brak przekonującej słowiańskiej etymologii. Po drugie fakt, że derywaty z tym sufiksem rzeczownikowym występują tylko na południu słowiańszczyzny. I, po trzecie, za pochodzeniem tureckim przemawia występowanie analogicznego sufiksu w języku tureckim. Za pochodzeniem słowiańskim, moim zdaniem, przemawia nieobecność tego sufiksu w języku albańskim ${ }^{8}$, który uległ znacznie silniejszemu wpływowi tureckiego niż języki słowiańskie.

W tureckim podobnie brzmiący sufiks używany jest w innych funkcjach niż słowiańskie -чe. Funkcjonuje głównie jako sufiks przysłówkowy. Zapewne dlatego nie zwrócił na siebie uwagi slawistów.

W języku tureckim sufiks ten tworzy głównie:

„a) nazwy języków, używane też jako przysłówki i stąd pozorne przymiotniki, np. Türk 'Turek' $\rightarrow$ Türkçe '1. język turecki; 2. po turecku';

b) przysłówki denominalne, np. ben 'ja' $\rightarrow$ bence 'po mojemu, moim zdaniem', yüzler 'setki”' $\rightarrow$ yüzlerce '(całymi) setkami'; hoş 'przyjemny' $\rightarrow$ hoşça 'przyjemnie', erkek 'mężczyzna' $\rightarrow$ erkekçe 'po męsku', evvel 'przed' $\rightarrow$ evvelce 'dawniej, wcześniej';

c) osłabienie przymiotnika, np. ak 'biały' $\rightarrow a k c ̧ a$ 'białawy', geniş 'szeroki' $\rightarrow$ geniş̧̧e 'szerokawy';

d) rzeczowniki (zwykle abstrakcyjne, sporadycznie też konkretne) od rzeczowników dewerbalnych na -ma, np. boğma 'duszenie' $\rightarrow$ boğmaca 'koklusz', çekme 'ciągnięcie' $\rightarrow$ çekmece 'szuflada';

e) onomastica denominalne, np. çamlı 'porośnięty sosnami' $\rightarrow$ Çamlıca (nazwa wzgórza widokowego w azjatyckiej części Stambułu).

8 Oprócz kilku zaledwie wyrazów o zasięgu dialektalnym: birçe 'synuś, nipçe 'wnuczuś’ (Newmark i in. 1982: 172), uważanych za sufiksy słowiańskie. Na pośrednictwo słowiańskie w skazuje forma birçe zamiast spodziewanej birxhe. 
[...] Poza tym tak brzmiący sufiks występuje w różnych formach czasownikowych, np. bakttkça 'ilekroć (po)patrzył', güldükçe 'w miarę tego, jak się śmiał"' (z prywatnej korespondencji z profesorem Markiem Stachowskim).

Nic $\mathrm{z}$ tego do słowiańskiej sytuacji nie pasuje. W funkcji deminutywnej czy hipokorystycznej w tureckim występują inne sufiksy. Na dodatek w standardzie tureckim sufiks ten nie derywuje od rzeczowników.

W tureckim występują w dystrybucji komplementarnej różne alomorfy tego sufiksu, związane harmonią wokaliczną i konsonantyczną: -çe/-ça/-ce/$-c a$. W macedońskim jest tylko forma - če, co, między innymi, sugeruje, że np. macedońskie nогачe jest bardziej zaadaptowane do słowiańskiej struktury słowotwórczej, niż serbska pogača, która zachowała bardziej tureckie brzmienie (oczywiście przy założeniu, że wyraz ten pochodzi z tureckiego, a nie $\mathrm{z}$ włoskiego). Alomorf - -ue także występuje w macedońskim, ale zwykle w kompletnych zapożyczeniach i na gruncie słowiańskim nie funkcjonuje jako sufiks, jak np. чекмеце 'skrzynka z szufladką na pieniądze', дереие 'trudne położenie', фepeue 'górna część ubioru żeńskiego, zakrywająca twarz'.

Śledząc odpowiedni ciąg informacji - informacje od rodzimych, tureckich użytkowników języka (za pośrednictwem profesora Marka Stachowskiego) oraz słuchając seriali tureckich - dowiaduję się oto, że sufiks -çe, w takiej głównie formie, funkcjonuje w tureckim języku potocznym, dokładnie w takiej samej funkcji jak w macedońskim czy innych językach południowosłowiańskich. W tureckim sufiks -çe derywuje deminutiva od rzeczownikowych podstaw żeńskich, np. Zeynepçe, Melikçe (zdrobnienia imion żeńskich Zeynep i Melike), też Sevçe, Birce. Por. „Sufiks ma tylko teoretycznie wszystkie cztery warianty fonetyczne, w rzeczywistości w tej funkcji najczęściej jest używany jako -çe, nawet jeśli to nie jest zgodne $\mathrm{z}$ harmonią ani samogłoskową, ani spółgłoskową. [...]. Tuğçe jest podwójnie błędne, bo powinno brzmieć Tuğca; natomiast Ayça i Sevçe są pojedynczo błędne, bo zamiast odpowiednio Ayca i Sevce". W funkcji hipokorystycznej -çe derywuje głównie od żeńskich imion. Por.:

„1. Podstawą są głównie imiona kobiet, ale także nazwy pokrewieństwa (typu babcia);

2. Sufiks ma charakter wysoce emocjonalny i gwarowy; 
3. Na różnych obszarach Turcji obowiązują różne zasady jego użycia; w języku literackim w takiej funkcji nie występuje wcale (chyba że w języku rodzinnym, np. klzçe - zamiast klzca! - 'córeczka');

4. Używany jest właściwie wyłącznie w funkcji wokatiwu” (Stachowski, jak wyżej) $)^{9}$.

Również $\mathrm{w}$ tej funkcji i formie sufiks -çe upowszechnił się w dialektach tureckich $\mathrm{w}$ Macedonii, co może być zarówno dziedzictwem potocznego/gwarowego tureckiego, jak i skutkiem oddziaływania słowiańskiego. Por. „(...) jakiś wpływ macedońskiego jest możliwy (choć niedowiedlny), ponieważ (...) rodzina [mowa o macedońskich Turkach - I.S.] pod Skopje też używa suf. dem. -çe w uogólnionej postaci, mówiąc np. kızçe 'dziewczynka' zamiast ogólnotur. kızca" (Stachowski, jak wyżej).

Wydaje się, że w wypadku słowiańskiego -чe skontaminowały się fakty językowe słowiańskie z tureckimi, czemu sprzyjało podobieństwo fonetyczne i występowanie w językach słowiańskich, w funkcji deminutywnej sufiksu -e $\left(z^{*}-e\right)$ i w ogóle podobnie brzmiących zakończeń wyrazowych. Wpływ tureckiego substandardu (form wokatywnych typu Zeynepçe, Melekçe) przejawił się we wzmocnieniu, utrwaleniu i wysokiej frekwencji słowiańskich zakończeń na -чe, niezależnie od tego, czy sufiks ten składa się w całości, w części lub wcale ze słowiańskich elementów.

Przekonującą słowiańską etymologię - чe przedstawił Borys Markov (Марков 1969: 261). Markov założył, że sufiks ten pochodzi ze słowiańskiego deminutywnego sufiksu -e $\left({ }^{*}-e\right)^{10}$, który wchłonął spółgłoskę tematu $\mathrm{z}$ tematów zakończonych na $-k^{11}$. Jest to najbardziej prawdopodobna hipote$\mathrm{za}$, ponieważ formacje $\mathrm{z}$ tematycznym $-k$ są bardzo częste, np. внуче 'wnuczek' (od внук), девојче 'dziewczynka' (od девојка), мајче 'mamusia' (od мајка). Z tego też względu uważa się, że sufiks ten w BCMS nie derywuje od podstaw zakończonych na $-k$, w związku $\mathrm{z}$ tym funkcjonuje $\mathrm{w}$ dystrybucji komplementarnej z sufiksem -e (Babić 2002: 428). Jednakże w bułgar-

9 Ten fragment tekstu został skomponowany z fragmentów listów od profesora Marka Stachowskiego spod różnych dat w roku 2020/2021.

10 Dawny sufiks *-e oznaczał głównie osobniki niedorosłe, rodzaju nijakiego (paradygmat odmiany nijakiej na -ę, -ęta w scs.). Stąd też współcześnie wszystkie derywaty na -e i -̌̌e mają gramatyczny rodzaj nijaki.

11 Być może też z tematami zakończonymi na -t, - $\check{c}$ lub - $c$ ?, np. лишчe 'listek' (od лист 'liść'), лисиче 'lisek' od лисица 'lis'. 
skim sufiks -e nie jest tak bardzo produktywny (por. Стакић 1988: 178). Ani w bułgarskim, ani w macedońskim nie ma hipokorystyków typu serbskich Bole (od Boško), Cile (znany mi Živojin był tak nazywany) (gdzie z kolei należałoby postulować sufiks -le?). To by wskazywało, że w macedońskim funkcjonuje też -чe innego pochodzenia. Podobnie Reczek, która uważa, że w gorańskim w takich formacjach w każdym kontekście spółgłoska stanowi część sufiksu, por. „w rzeczownikach deminutywnych zakończonych na -çe, a powstałych od rzeczowników rodzaju żeńskiego na -ka lub rzeczowników rodzaju nijakiego na -ko, wyróżniam formant deminutywny -çe, uznając, że w procesie tworzenia zdrobnień dochodzi w tym wypadku do wymiany formantów" (Reczek 2009: 6), w dalszym ciągu sugeruje, że w taki sposób formacje te są rozumiane przez rodzimych użytkowników języka. W gorańskim ewidentnie tak właśnie jest, bo w nowszych formacjach mamy, na przykład, çajnik 'czajnik' $\rightarrow$ çajnikçe 'czajniczek', çakmak 'zapalniczka' $\rightarrow$ çakmaçe/çakmakçe 'mała zapalniczka'; çibuk 'lufka' $\rightarrow$ çibuçe/çibukçe 'lufeczka', hendek 'rów' $\rightarrow$ hendeçe/hendekçe 'rowek'. Tutaj -çe łączy się z tematami zakończonymi na $-k$, a zachowaniu grupy kç zapewne sprzyja bliskość albańskiego, który łatwo akceptuje grupy spółgłoskowe o podobnych strukturach (przykłady gorańskie pochodzą z terenu Albanii (za Reczek 2009). Podobne formacje występują także w całej zachodniej Macedonii i dają świadectwo temu, że także przy tematach zakończonych na $-k$ występuje sufiks -чe, a nie -e. Później jednak grupa spółgłoskowa może się uprościć, jak widać, i formacja funkcjonuje w postaciach fakultatywnych ${ }^{12}$. W słowiańskich tematach na - $k$ utrwaliło się - e nie -çe, por. gorańskie çujek 'człowiek' $\rightarrow$ tylko çujeçe 'człowieczek'. dejka 'dziewczyna' $\rightarrow$ dejçe 'dziewczynka'. Por. też macedońskie oboczne волкче і волче 'wilczek' $\leftarrow$ волк 'wilk'.

Tak więc, sufiks - $e$ wchłonął $-k$ tematyczne, często pochodzące $\mathrm{z}$ innego sufiksu. Sufiksy deminutywne niezwykle często kontaminują się ze sobą, por. np. gorański niewątpliwie skontaminowany sufiks -içe: çashiçe 'szklaneczka' (od çasha 'szklanka' lub çashica, gmuçka 'grudka' $\rightarrow$ gmuçkiçe 'grudeczka'; gnezdo 'gniazdo' $\rightarrow$ gnezdiçe 'gniazdko', czy dejka 'dziewczyna’ $\rightarrow$ dejçe 'dziewczynka’ $\rightarrow$ dejçurçe 'dziewczyneczka'). Por. też inne zło-

12 Również w tureckim tematyczne wygłosowe $-k$ przeważnie odpada w dawnych derywatach deminutywnych z sufiksem - cik, np. ayacık 'nóżka' od ayak 'noga', köpecik 'piesek' od köpek 'pies' i in. (Stachowski 2007: 101). 
żone sufiksy deminutywne, jak -анче, -енче, -инче, np. mac. кафеанче 'kawiarenka', главинче 'środeczek'.

Ostateczne rozstrzygnięcie problemu pochodzenia sufiksu -че mogłaby dać informacja o tym, czy formacje słowotwórcze tego typu występują w starych tekstach z podstawami słowiańskimi i od kiedy. Występowanie tureckich pożyczek w tekstach słowiańskich jest zaświadczone od początku XVI wieku, a przyłączanie tureckich sufiksów do podstaw słowiańskich - od wieku XVII (Dybo 2020, Radić 2001). Nikt nie badał starego piśmiennictwa południowosłowiańskiego ze względu na ten konkretny przyrostek. W najstarszych tekstach (scs) takich formacji słowotwórczych na pewno nie ma. Wprawdzie już w XV w. pojawiają się w Macedonii nazwy miejscowe typu Конче (і Конча), Бенче, Врапче, o których sądzi się, że raczej mają pochodzenie dzierżawcze ${ }^{13}$. Na razie należy pozostać przy słowiańskim pochodzeniu tego formantu, który jednak, moim zdaniem, bez tureckiego wsparcia nie zrobiłby takiej kariery w języku macedońskim.

Tak czy inaczej, moim zdaniem, hipoteza o osmańskim wkładzie w rozwój sufiksu -чe/-če w językach południowosłowiańskich zasługuje na uwagę. Obecność tureckiego sufiksu w miejscowych tureckich dialektach, też jego obecność w zapożyczeniach wzmocniła frekwencję użycia sufiksu w formacjach słowiańskich (a to rykoszetem wzmocniło jego użycie w miejscowych dialektach tureckich w konkretnej funkcji i formie nie reagującej ani na harmonię konsonantyczną, ani na wokaliczną). Istotnym argumentem jest zwłaszcza to, że sufiks ten na taką skalę funkcjonuje tylko w tych językach, których tereny etniczne wchodziły w skład Turcji - w serbskim, macedońskim i bułgarskim. W chorwackim i słoweńskim -če występuje znacznie rzadziej. Dla porównania w słoweńskim słowniku a tergo ${ }^{14}$ naliczyłam około 80 słów zakończonych na -če, z czego oczywiście tylko część to formy deminutywne rzeczownika. To niewiele w porównaniu z macedońskim, gdzie znalazłam około 1000 słów na -чe).

Por. „Despite signifficant progress in the study of Turkic-Slavic language contacts, which took place from the mid-20th century, there are a signifficant

13 Tzn. z sufiksu -jb (Станковска 2002).

$14 \mathrm{http}$ //bos.zrc-sazu.si/cgi/neva.exe?name=odzadnji\&expression=\%E8e (dostęp 20.04.2021). 
number of unresolved and controversial problems related mainly to the time and ways of penetration of speciffic early lexical borrowings" (Dybo 2020).

Tak czy inaczej, synchronicznie należy postulować sufiks -че także w takich formacjach, w których 4 pochodzi wygłosowej spółgłoski tematu (np. внуче) i zakłada regułę derywacyjną upraszczającą grupę spółgłoskową (nр. внук + че $\rightarrow$ внукче $\rightarrow$ внуче). Zresztą zdrobnienie od волк to волкче, znacznie rzadziej волче (które częściej używane jest w znaczeniu 'mały wół'), co potwierdza niezależność -чe od $-e$.

\section{Bibliografia}

BABIĆ S., 2002, Tvorba riječi u hrvatskome književnome jeziku, Zagreb: Globus.

Belić A., 1901, Zur Entwicklungsgeschichte der salvischen Deminutiv- und Amplificativsuffixe, Archiv für slavische Philologie XXIII, s. 134-206.

Belić A., 1904, Zur Entwicklungsgeschichte der salvischen Deminutiv- und Amplificativsuffixe 2, Archiv für slavische Philologie XXVI, s. 321-357.

DŁugosz N., 2020, Bałkańskie cechy języka Goran w zakresie słowotwórstwa (na przykładzie wybranych formacji słowotwórczych), Zeszyty Łużyckie 54, s. $129-142$.

Dyво A. V., 2020, Turkic Languages and Slavic, w: M.L. Greenberg (red.), Encyclopedia of Slavic Languages and Linguistics Online, [online:] http://dx.doi. org/10.1163/2589-6229_ESLO_COM_032504.

KLAJN I., 2003, Tvorba reči u savremenom srpskom jeziku 2, Beograd: Zavod za Udžbenike i Nastavna Sredstva.

Matasović R., 2014, Slavic Nominal Word-Formation. Proto-Indo-European Origins and Historical Development, Heidelberg: Universitätsverlag, Winter.

Miklosich F., 1889, Über die Einwirkungen des Türkischen auf die Grammatik der südosteuropäischen Sprachen, Vienna: Tempsky.

Newmark L., Hubbard Ph., Prifti P., 1982, Standard Albanian. A reference grammar for students, Stanford: Stanford University Press.

Petrović S., 1993, Istorija i stanje proučavanja turcizama u srpskohrvatskom jeziku, Zbornik Matice srpske za filologiju i lingvistiku 36/2, s. 71-128.

Petrović S., 2012, Turcizmi u srpskom prizrenskom govoru, Beograd: Institut za srpski jezik SANU.

Pintarič M., 2012, On Turcisms in Slovenian, Vestnik za tuje jezike 4/1-2, s. 79-81.

RADIĆ P., 2001, Turski sufiksi u srpskom jeziku (sa osvrtom na stanje u makedonskom i bugarskom), Beograd: Institut za srpski jezik SANU. 
RECZEK N., 2009, Uwagi o deminutywach gorańskich (na podstawie materiału słownikowego), Slavia Meridionalis 9, s. 1-11.

SAWICKA I., KARASIŃSKi A., 2018, Bałkańskie adaptacje tureckiego sufiksu -çi/-ci, Slavia Meridionalis 18, s. 1-13.

SAzdov S., 2019, On the turkish origin of the suffix -lija in Macedonian, w: V. Latifi, V. Friedman, M. Markovikj (red.), Multiculturalism and language contact, Tetovo: Scientific Institute Max van der Stoel, s. 195-207.

ŠKalJIĆ A., 1966, Turcizmi u srpskohrvatskom jeziku, Sarajevo: Svijetlost.

Sкок P., 1937/1938, Prilozi proučavanju turcizama u srpskohrvatskom jeziku, Slavia XV.

Sкок P., 1971, Etimologijski rječnik hrvatskoga ili srpskoga jezika, Zagreb: Jugoslovenska akademija znanosti i umjetnosti.

SokoŁowski J., 2007, Mechanizmy deminucji i hipokoryzacji w języku macedońskim i polskim na tle innych języków słowiańskich, w: Z. Rudnik-Karwatowa (red.), Z polskich studiów slawistycznych, seria 11, Językoznawstwo. Prace na XIV Międzynarodowy Kongres Slawistów w Ochrydzie 2008, Warszawa: Komitet Słowianoznawstwa PAN, s. 211-219.

Stachowski M., 2007, Gramatyka języka tureckiego w zarysie, Kraków: Księgarnia Akademicka.

Stachowski M., 2017, Kilka uwag o zapożyczeniach tureckich w dialekcie macedońskim Bitoli, Rocznik Slawistyczny 66, s. 95-101.

Stachowski S., 1967, Studia nad chronologia turcyzmów w języku serbsko-chorwackim, Kraków: Uniwersytet Jagielloński.

Stachowski S., 1971, Studia nad chronologia turcyzmów w języku bułgarskim, Kraków: Uniwersytet Jagielloński.

StachowsKi S., 1973, Fonetyka zapożyczeń osmańsko-tureckich w języku serbskochorwackim, Kraków: Uniwersytet Jagielloński.

StramluǏC-Breznik I., (red.), 2015, Manjšalnice v slovanskih jezikih: oblika in vloga, Maribor: Zora.

АвРАмова Ц., 2016, Деминутивите като речникови единици, w: D. Blagoeva, S. Kolkovska (red.), Lexicography at the Beginning of 21st Century, Sofia: Marin Drinov, s. 89-98.

АризАнковскА Л., 2012, Зборообразувааето и неговите ресурси во македонскиот јазик (со осврт на дериватите со субјективна оценка како дел од основниот лексички фонд на македонскиот јазик), w: Р. Драгичевић (red.), Творба речи и њени ресурси у словенским језицима. Београд: Филолошки факултет, s. $33-42$.

АризАнковскА Л., 2015, Деминутивите во македонскиот јазик и нивната функција, w: I. Stramljič Breznik (red.), Manjšalnice v slovanskih jezikih: oblika in vloga, Maribor: Zora, s. 37-49. 
Асенова П., 2002, Балканско езикознание. Основни проблеми на балканския езиков съюз, Велико Търново: Фабер.

ДРАГИчЕвИЋ Р. (red.), Творба речи и њени ресурси у словенским језицима. Београд: Филолошки факултет.

Дрвошанов В., 2012, Деминутивно-хипокористични образуванија од хуманитарната анатомија во македонските говори, w: Лексиката со субјективна оценка во македонскиот јазик, Скопје: Институт за македонскиот јазик Крсте Мисирков.

ЈАШАР-НАСТЕВА О., 2001, Турските лексички елементи во македонскиот јазик, Скопје: Институт за македонскиот јазик Крсте Мисирков.

ЈовАновА-ГруЈовскА Е., 2009, Лексичко-семантичка анализа на именките со субјективна оценка во македонскиот јазик (деминутиви, хипокористищи, аугментативи, пејоративи), Скопје: Универзитет Св. Кирил и Матодиј.

Конески К., 1995, Зборообразувањето во современиот македонски јазик, Скопје: Бона.

Коруьин Б., 1990, Придавките на туѓа основа во македонскиот јазик, w: На македонскограматички теми, Скопје: Институт за македонскиот јазик Крсте Мисирков, s. 135-157.

МАрков Б., 1969, Наставки со експресивно значење кај именките, Годишен зборник на Филозофскиот факултет, кн. 21, s. 245-300.

Речник српскохрватскога књижевног језика, 1967-1976, Novi Sad: Matica srpska.

ПАновскА Р., 1973., Стилистичката улога на деминутивно-хипокористичната лексика во македонската народна поезија, Македонски Јазик, XXIV, s. $63-75$.

СоБолев А.Н., 2004, Опыт исследования тюркизмов в балканских диалектах, Zeitschrift für Balkanologie 40/1, s. 61-91; 40/2, s. 206-229.

ТополињскА 3., 1979, Граматичкиот статус на формациите со суфиксот -лија во македонскиот литературен јазик, w: Т. Саздов (red.), Зборник на трудови од V научна дискусија, Скопје: Универзитет Св. Кирил и Матодиј, s. 13-19.

Соколовски J., 2013, Механизми на деминуција и хипокоризација во македонскиот и полскиот јазик врз фонот на другите словенски јазици, Studia Linguistica Polono-Meridianoslavica 14, Скопје.

Соколовски J., 2018, Македонски и полски деминутиви во текстот - обид за конфронтација, w: XLIV меѓународна научна конферениија намеѓународниот семинар за македонски јазик, литература и култура, Скопје: Универзитет Св. Кирил и Матодиј, s. 35-45.

СтАкић М., 1988, Дериваџиона фонетика именица и придева у јужнословенским језицима, Београд: Филолошки факултет Београдског универзитета. 
Цветковски V., 2017, Етнолингвистички особености на турските лексички заемки во колоквијалниот македонски јазик во Битола, Скопје: Македонска академија на науките и уметностите.

ФАСмеР М., 1987, Етимологический словарь русского јазыка, т. 4, Москва: Прогрес.

\section{Reflections on Turkish suffixes in Macedonian ( s u m mar y)}

In the article the grammatical / morphological problems generated by the Macedonian suffixes borrowed from the Turkish language are listed. The main topic is the etymology of the Slavic diminutive-hypocoristic suffix -чe. The possible influence of Turkish on the persistence and frequency of this suffix is considered.

Ke y w ord s: Macedonian; Turkish loans; word formation; suffixes; etymology 